\title{
Fuelling the Pacific: Aid for renewable energy across Pacific Island countries
}

\author{
Carola Betzold* \\ University of Gothenburg, School of Global Studies, PO Box 700, Gothenburg 40530, Sweden
}

\section{A R T I C L E I N F O}

\section{Article history:}

Received 10 November 2014

Received in revised form

11 September 2015

Accepted 17 December 2015

\section{Keywords:}

Pacific island countries

Aid/development assistance

Renewable energy

Electrification

\begin{abstract}
A B S T R A C T
Pacific island countries have strong economic, political and environmental incentives to switch from imported fossil fuels to indigenous renewable energy technologies, and are well positioned to achieve such a switch, given their ample renewable energy potential as well as their ambitious renewable energy goals. For the Pacific island countries to reach these goals, however, they depend on donor funding. This paper therefore analyses energy-related aid to the South Pacific from 1990 through 2012, and specifically evaluates its development in three areas: energy technology, grid vs. off-grid solutions, and project components. Using data from the Organisation of Economic Cooperation and Development, I find a recent shift in donor thinking: donors have, over the past years, put greater emphasis on renewable energy, especially hydro and increasingly solar power. Donors have also invested more in off-grid solutions - often solar-powered. Finally, donors have begun to focus more on 'software', that is, capacitybuilding, training and policy-making. If Pacific island countries, together with the donors, continue on this path, they are well-positioned to reach their ambitious renewable energy goals - and to serve as an example for other countries, both developing and developed, islands and non-islands.
\end{abstract}

(c) 2015 Elsevier Ltd. All rights reserved.

\section{Contents}

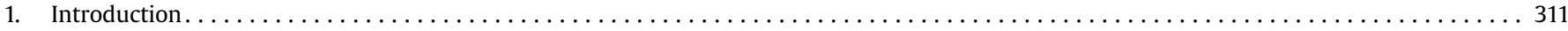

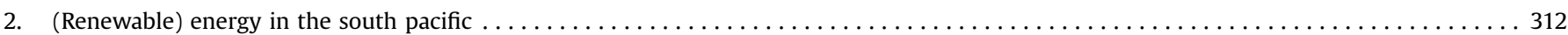

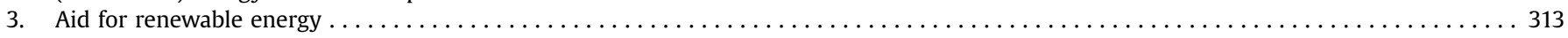

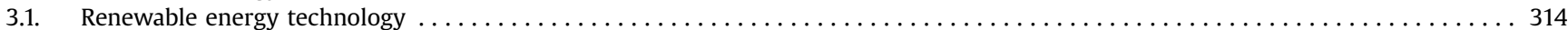

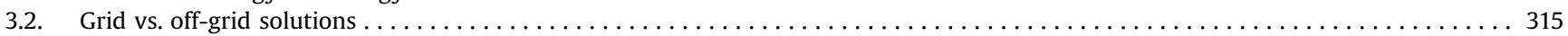

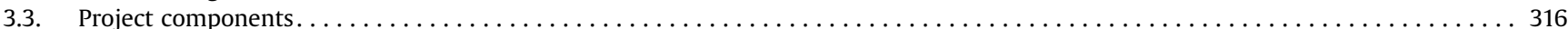

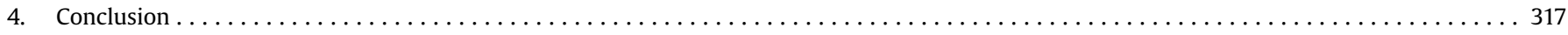

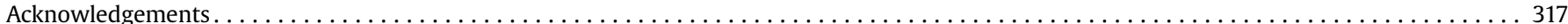

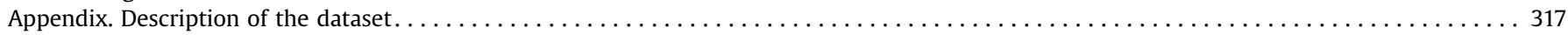

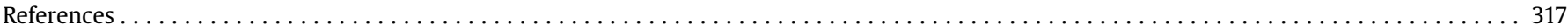

\section{Introduction}

Pacific island countries (PICS) are among the first and worst affected by climate change. At the same time, their own greenhouse gas emissions are minute on a global scale. Yet, even if greenhouse gas reductions in small island states - in the Pacific

\footnotetext{
* Tel. +46 317865806 .

E-mail address: carola.betzold@gu.se
}

and beyond - will not be felt globally, they are important for two reasons: First, every greenhouse gas reduction counts: a ton of carbon dioxide saved is a ton of carbon dioxide saved. Second, and more importantly, small island states seek to lead by example and demonstrate to larger emitters that reductions are feasible - not least to gain credibility and moral leverage in the global climate change negotiations [e.g., 1,2].

The energy sector offers the biggest opportunity for PICS to reduce their greenhouse gas emissions, since almost all of their greenhouse gas emissions are from fossil fuels imported for power 
generation and transport. A switch to renewable energy, in particular for power generation, would not only improve PICs' environmental performance, but also help to reduce expensive imports and reduce vulnerability to price volatility and insecure fuel supply. Accordingly, most pIcs have put forward ambitious renewable energy goals; the Cook Islands, Niue and Tuvalu, for instance, all aspire to have 100 percent renewable electricity by $2020([3,4]$; see also Table 2).

For the PICs to reach these goals, however, they depend on external funding and aid. Renewable energy technologies typically require high upfront capital, which governments and households lack across the pics. Donor support is thus central. But how has energy-related aid to the Pacific developed over time? This paper takes a closer look at data on energy-related aid from the Organisation of Economic Cooperation and Development (OECD) Credit Reporting System (CRS) from 1990 through 2012. After an overview of the present (renewable) energy landscape in PICs, the paper examines where energy-related aid is flowing to, in terms of renewable energy technology, grid vs. off-grid solutions, and project components. The results indicate a shift in energy-related aid over the past years: toward renewable energy, toward off-grid solutions and toward policy-making and capacity-building. Much remains to be done; yet, if the Pacific island countries, together with the donors, continue to pay attention to different renewable energy technologies, rural electrification, and 'software', they can reach their renewable energy goals - and serve as an example for other countries, in the Pacific and beyond.

\section{2. (Renewable) energy in the south pacific}

The focus here is on the 14 PICs that are members of the Secretariat of the Pacific Community (SPC). While they differ considerably in terms of land area, population and population density, geography, and gross domestic product (GDP), as Table 1 shows, these countries also share common development challenges, related to their insularity, relative remoteness, geographic fragmentation, and overall small size [e.g. 5,6].

These island characteristics also affect the energy situation in PICS, as Table 2 illustrates. In some countries, especially in the single-island countries of Nauru and Niue, almost everyone has access to electricity. In rural areas and remote outer islands, in contrast, households have only limited access to electricity. Particularly in the larger, Melanesian countries - Papua New Guinea, the Solomon Islands and Vanuatu - access to electricity is very low, at 20 percent or less. Although some households may instead have access to basic electrification through small-scale off-grid installations, many households, especially rural households, are not electrified. While national averages vary (see Table 2 ), overall, 70 percent of households in the Pacific lack access to electricity (50 percent if Papua New Guinea is excluded; [7]).

It is thus not surprising that in many PICS, traditional biomass, mostly wood or coconut residues, significantly contribute to primary energy needs e.g. [8]. Overall, however, imported fossil fuels dominate, as Fig. 1 clearly indicates. Energy, in particular in rural areas, is largely from diesel generators - they provide an estimated 78 percent of all (modern) energy [3]. Yet, diesel generators have several disadvantages: they often run just a few hours per day; they may be idle for long periods while awaiting repair or fuel, often from other islands [7,9]; and they are 'the most expensive form of power for most situations in the region', according to a recent International Renewable Energy report [3, page3]. Electricity is indeed extremely expensive in PICs, with electricity tariffs of on average 35 usD cents per kWh, but reaching as high as 1.50 usD per kWh in outer islands (see Table 2; [3]). High prices are due to remoteness and associated high transport costs, diseconomies of scale and small market sizes [10], and so PICs spend a significant

Table 2

Energy in the Pacific island countries.

\begin{tabular}{|c|c|c|c|c|c|c|}
\hline \multirow{2}{*}{$\begin{array}{l}\text { Country } \\
\text { Cook Islands }\end{array}$} & \multirow{2}{*}{$\begin{array}{l}\text { Access to } \\
\text { electricity } \\
(\%)\end{array}$} & \multirow{2}{*}{$\begin{array}{l}\text { Fuel } \\
\text { imports } \\
\text { (\% of } \\
\text { GDP) }\end{array}$} & \multirow{2}{*}{$\begin{array}{l}\begin{array}{l}\text { Diesel } \\
\text { price } \\
\text { (USD) }\end{array} \\
1.63\end{array}$} & \multirow{2}{*}{$\begin{array}{l}\text { Electricity } \\
\text { tariff (USD/ } \\
\text { kWh) }\end{array}$} & \multicolumn{2}{|c|}{$\begin{array}{l}\text { Renewable } \\
\text { energy } \\
\text { targets }\end{array}$} \\
\hline & & & & & 100 & 2020 \\
\hline Fiji & 60 & 13.3 & 0.70 & 0.17 & 90 & 2015 \\
\hline Kiribati & 60 & 9.0 & 1.11 & 0.44 & 28 & 2025 \\
\hline $\begin{array}{l}\text { Marshall } \\
\text { Islands }\end{array}$ & 75 & 26.6 & 1.48 & 0.37 & 20 & 2020 \\
\hline $\begin{array}{c}\text { Micronesia } \\
\text { (Fed. } \\
\text { States) }\end{array}$ & 54 & 12.5 & 1.25 & 0.42 & 30 & 2020 \\
\hline Nauru & 100 & 8.5 & 1.55 & 0.14 & 50 & 2015 \\
\hline Niue & 99 & 19.9 & 1.63 & 0.43 & 100 & 2020 \\
\hline Palau & 100 & 11.9 & 0.93 & 0.32 & $20^{*}$ & 2020 \\
\hline $\begin{array}{r}\text { Papua New } \\
\text { Guinea }\end{array}$ & 10 & 5.6 & 0.91 & 0.21 & na & na \\
\hline Samoa & 97 & 16.9 & 0.81 & 0.28 & $10^{*}$ & 2016 \\
\hline $\begin{array}{l}\text { Solomon } \\
\text { Islands }\end{array}$ & 14 & 16.4 & 0.98 & 0.51 & $20 *$ & 2020 \\
\hline Tonga & 92 & 10.4 & 0.95 & 0.36 & 50 & 2020 \\
\hline Tuvalu & 98 & 20.7 & 1.51 & 0.40 & 100 & 2020 \\
\hline Vanuatu & 19 & 6.0 & 1.36 & 0.37 & $65^{*}$ & 2020 \\
\hline average & 70 & 14.7 & 1.20 & 0.35 & na & na \\
\hline
\end{tabular}

* Target refers to primary energy supply. Data from [4]. Access to electricity from [37]. All other data for 2009, from [38].

Table 1

The Pacific island countries.

\begin{tabular}{|c|c|c|c|c|c|}
\hline Country & Land area $\left(\mathbf{k m}^{2}\right)$ & Population (000) & Population density & GDP/cap (USD) & Geography \\
\hline Cook Islands* & 240 & 21 & 86 & 10,300 & 14 islands \\
\hline Fiji & 18,270 & 875 & 48 & 3612 & 320 islands, 106 inhabited \\
\hline Kiribati & 810 & 101 & 124 & 1160 & 32 widely scattered atolls \\
\hline Marshall Islands* & 180 & 53 & 292 & 2879 & 34 islands, mostly atolls \\
\hline Micronesia (FS)* & 700 & 103 & 148 & 2443 & 607 islands \\
\hline Nauru & 21 & 10 & 471 & 6954 & Single island \\
\hline Niue* & 261 & 1.5 & 6 & 5800 & Single island \\
\hline Palau* & 460 & 21 & 45 & 9281 & 596 islands, 12 inhabited \\
\hline Papua New Guinea & 452,860 & 7167 & 16 & 1076 & Over 600 islands \\
\hline Samoa & 2830 & 189 & 67 & 2350 & 10 islands \\
\hline Solomon islands & 27,990 & 550 & 20 & 1145 & ca. 1000 islands, 350 inhabited \\
\hline Tonga & 720 & 105 & 146 & 2658 & 176 islands, 36 inhabited \\
\hline Tuvalu & 30 & 10 & 329 & 2624 & 9 atolls \\
\hline Vanuatu & 12,190 & 247 & 20 & 2112 & Over 80 islands, 65 inhabited \\
\hline
\end{tabular}

* Countries freely associated with New Zealand (Cook Islands and Niue) or the United States (Marshall Islands, Federated States of Micronesia and Palau). All data for 2012. Population density is inhabitants per $\mathrm{km}^{2}$, GDP in constant 2010 USD.Sources: Land area, population and GDP data from [35] and [36]; geography from [3]. 


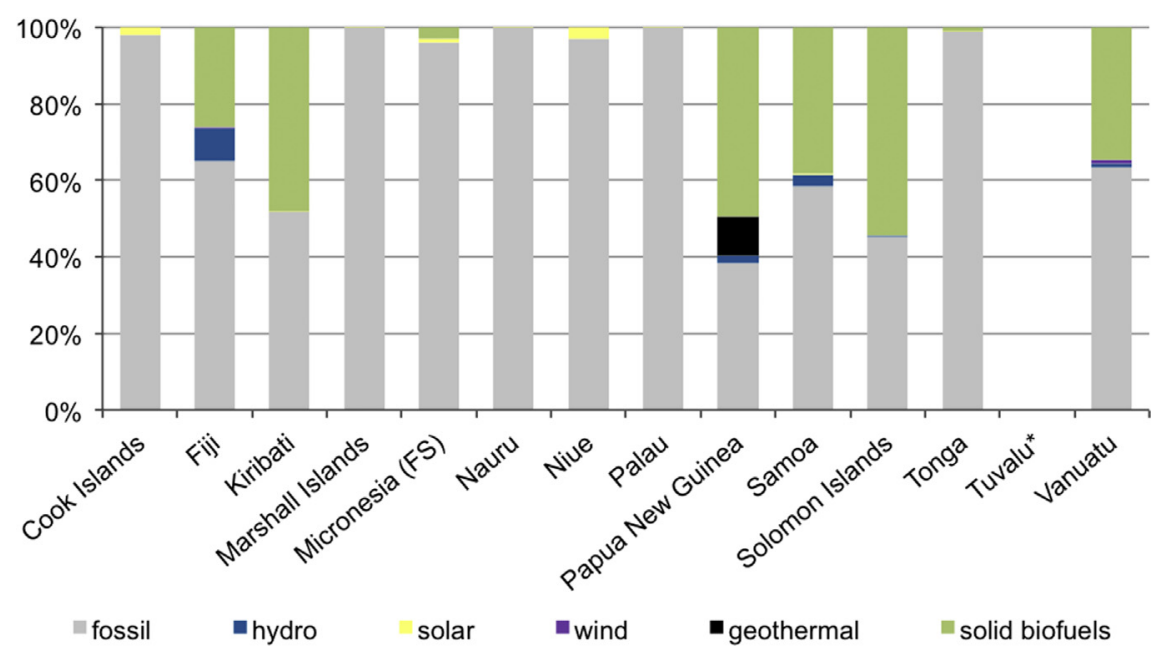

Fig. 1. Primary energy supply in Pacific island countries (data for 2009). Source: [34].* no data.

- and growing - part of the gross domestic product (GDP) on fossil fuel imports - on average 15 percent of their GDP, but the figure can be as high as 28 percent of GDP (see Table 2; [11,6]).

PICS clearly have strong incentives to transition toward renewable energy, and are indeed well positioned to do so. Being located in the tropics, sunshine for solar power is readily available everywhere. So is wind, although wind is very site-specific and the best sites may not be accessible. The problem with wind is thus less its availability but rather how to harness it [12]. The larger, mountainous islands of Melanesia as well as Fiji and Samoa are also rich in opportunities for hydro, geothermal, and biomass. Coconuts - omnipresent in the South Pacific, including in smaller islands - can be made into biofuel and used as a substitute for diesel in transport as well as diesel generators (for an overview of renewable energy resources, see e.g. [3,7]).

Not least as a result of high and rising fuel prices in the mid2000s, PICs have sought to tap their renewable energy potential. At the regional level, the 2002 Pacific Islands Energy Policy and Plan envisions 'available, reliable, affordable, and environmentally sound energy for sustainable development for all Pacific islanders'. While this vision includes reliable and affordable petroleum products, it emphasises the need to increase the share of renewable energy [13,6]. The 2011 'Framework for Action on Energy Security in the Pacific' revises the 2002 policy; its vision is 'an energy secure Pacific', where 'all people at all times have access to sufficient sustainable sources of clean and affordable energy' [14].

Nationally, the international and regional policies translated into national energy plans and strategic action plans, with sometimes very ambitious renewable energy goals. The Cook Islands, Niue and Tuvalu, for instance, all seek to achieve 100 percent renewable energy by 2020, while Fiji has ambitions to increase the share of renewables to 90 percent by 2015 (see Table 2; [4,3]).

These regional visions and national goals are very much in line with international initiatives, notably the United Nations Decade of Sustainable Energy for All. The initiative, running from 2014 to 2024, similarly emphasises universal energy access, energy efficiency and renewable energy, and has a strong focus on small island developing states, including those in the Pacific [15].

\section{Aid for renewable energy}

In order to reach their goals, PICS need not only international initiatives like the Sustainable Energy for All campaign, but also, and especially, donor support. Renewable energy projects have often been carried out only when and where donor funding is available $[16,17,10]$. Donors provided funds in particular after the 1970s oil shock, and so close to 430 million USD came into the region for renewable energy projects in the period from 1980 to 1990 [18]. Interest in renewable energy waned in the 1990s [18], but resurged in the 2000s, following high oil prices and climate change discussions [16]. Increasing amounts of funding are thus available for (renewable) energy; sPc estimated that donors allocated 300 million uSD to the energy sector for the period from 2010 to 2015 [14].

My own estimate puts the total amount of donor funding for energy from 1990 through 2012 at 669 million uSD in commitments, based on date from the OECD CRS. ${ }^{1}$ Relying on project title, project descriptions, and project purpose codes, I extracted a total of 699 energy-related entries, which I then coded according to their focus on renewable energy, technology supported, project components, and grid/off-grid solutions. The actual number of projects differs, as some projects may have several entries and thus have been double-counted. ${ }^{2}$ The amount of aid committed, in contrast, more accurately reflects renewable energy activities in the PICS, and so in the following descriptive analysis, I will only refer to the aid committed.

Over the period under analysis, from 1990 through 2012, 44 percent of energy-related commitments - 291 million out of 669 million USD - went to renewable energy. In particular since the late 2000s, donors have mainly funded renewable energy projects, whereas in earlier years, relatively more funding supported nonrenewable projects. Yet, not all of these projects were necessarily fossil fuel projects, as the figures also include projects such as power sector reforms that apply to both renewable and conventional energy. Overall, however, the data suggest a shift in focus toward renewable energy, as also the number of renewable energy projects indicates (see Fig. 2).

In terms of recipient countries, a large part of renewable energy aid went to the larger Melanesian island countries of Papua New Guinea and Vanuatu (57 million usD, 20 percent of all renewable energy aid; and 48 million usD, 16 percent, respectively), as well as to the Polynesian countries of Samoa and Tonga (32 million USD, 11 percent; and 35 million USD, 12 percent, respectively). When taking into account population size, we see the smallest countries among the main recipients of renewable energy aid per capita: Niue, with its population of just 1500 , received a total of 3836 usD per capita over the period

\footnotetext{
${ }^{1}$ All figures in 2012 constant USD, based on the OECD 2012 deflators, see [19].

2 See the appendix for a more detailed description of the dataset.
} 
of analysis; Nauru, 1173 uSD per capita, and the Cook Islands, 590 usD per capita.

Despite donor funding, progress toward more renewable energy has been relatively slow, as policy makers themselves admit, e.g. [13]. For older projects in particular, Jafaar concludes that 'renewable energy technologies have largely failed to develop into viable alternatives to conventional approaches' [8, page 307]; an International Renewable Energy Agency report similarly writes that' "many of the past [renewable energy] systems deployed in the picts PIcts [Pacific island countries and territories] have not performed according to expectations', although the success rate has improved in the past years, according to their report [3, page 4]; see also e.g. [20,21]. Studies put forward several reasons to explain the underperformance of past projects, including lack of finance, lack of capacity, lack of awareness, and lack of institutional frameworks, e.g. $[11,16,22,23]$. How have donors - as well as island governments - responded to these challenges, and what are the prospects for the PIcs' transition toward renewable energy? The following sections review the development of energyrelated OECD aid to the South Pacific from 1990 through 2012 in three areas: the technology support, focus on grid or off-grid solutions, and project components (Fig. 3).

\subsection{Renewable energy technology}

Which technology do energy-related aid projects use? Fig. 4 depicts the cumulative amount of aid by energy technology. A large number of project entries in the OECD dataset (440 entries corresponding to 235 million USD, or 35 percent of all energyrelated aid) contain no specific energy source, in part since this is not applicable, for instance when the project was about a general power sector reform. For the remaining projects - projects that indicated a specific energy source - most funding targeted fossil fuels. 222 million usD, one third of all energy-related aid, went into fossil fuel projects. The remaining third of energy-related aid supported renewable energy, and here mainly hydropower (119 million USD, 18 percent of all energy-related aid) and solar power (86 million USD, 13 percent). Relatively little aid ( 7 million usD, one percent) focused on other renewable energy technologies, such as wind, geothermal or biofuel.

Hydropower - often large-scale hydropower plants, mainly in Papua New Guinea and Samoa as well as Vanuatu - has received significant funding throughout the period of analysis, with a spike in 2011 due to a large Asian Development Bank hydropower project in Papua New Guinea. Fiji and the Solomon Islands also have potential for (small) hydropower stations, but received only little

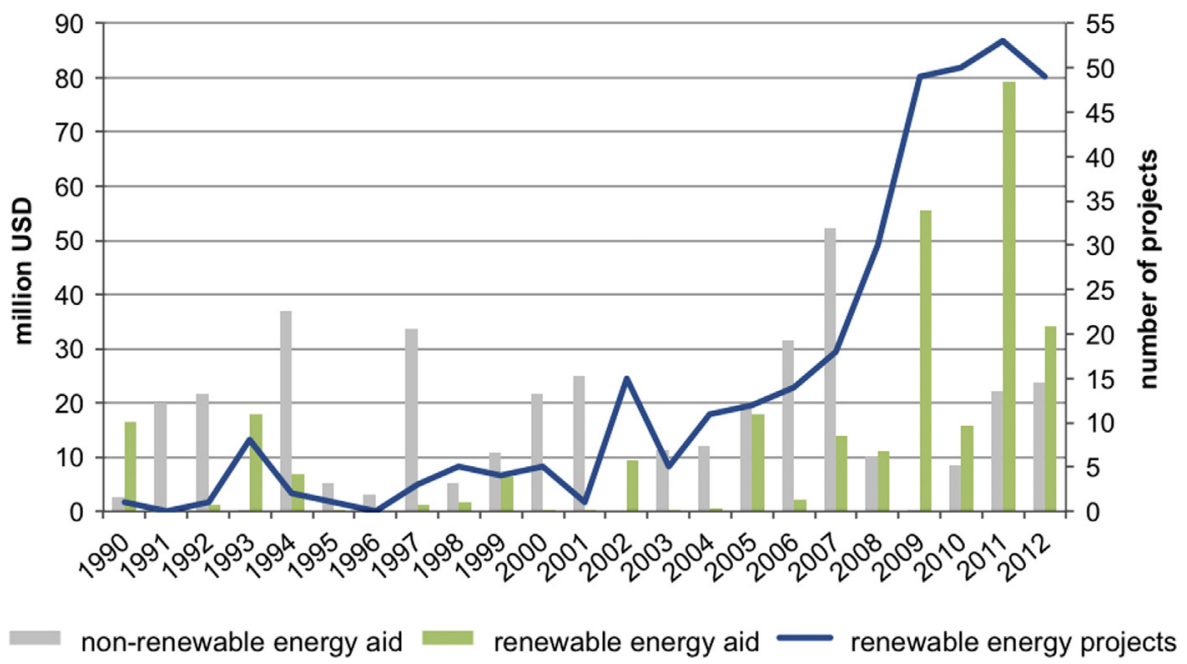

Fig. 2. Energy-related aid to the Pacific island countries from 1990 through 2012. Source: Based on OECD CRS Dataset.

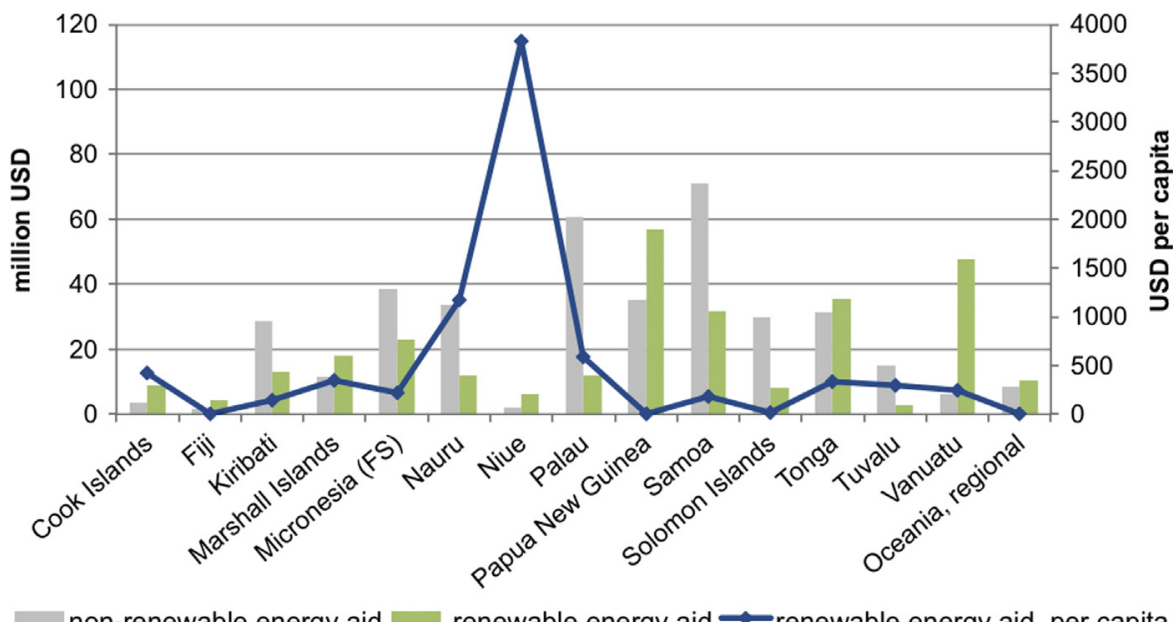

Fig. 3. Energy-related aid to the Pacific island countries, by recipient country. Source: Based on oECD CRS Dataset. 
aid for hydropower projects. In the smaller PICs, hydro may not be available at all [3, page 21].

Solar power, in contrast, is widely available throughout the PICs. Support for solar power has taken off in 2008; it has mainly targeted remote rural areas, where donors provide solar home systems (sHs). Yet, the utility of solar solutions has come under critique. Ref. [24], for instance, write that 'while donors have spent many millions of dollars to fund the purchase and installation of these [photovoltaic lighting] systems this initiative has yet to prove its sustainability', pointing among other things to the solid waste of solar home systems that cannot be recycled in remote islands. A study of Kiribati notes technical and maintenance problems; additionally, it finds that many i-Kiribati were unable to afford solar home systems, even with subsidies [25]. Finally, solar systems did not automatically lead to income-generating activities, but had only a 'very modest' impact on household income, while fees diverted income from other needs [25, page 361]; see also e.g. [23].

Solar power has a lot of promise; this promise notwithstanding, it is well worth exploring other renewable energy technologies. Biofuel for instance can be produced from different plants, including coconut oil. Coconut oil may be of interest for remote areas in particular where transportation costs are even higher, and can be used in diesel generators as well as for transport [7,3,26]. Bagasse - sugar cane residues - are used in non-Pacific sugar-producing islands like
Reunion Island [27] or Mauritius [26] and may also be of interest to Pacific islands like Fiji [28]. Hybrid systems that combine several renewable energy technologies, or renewable with conventional energy technologies, may help overcome the disadvantages of individual technologies, and have been found most appropriate and costeffective in case studies, as on Fiji [29].

Clearly, there is no single most appropriate renewable energy technology for PICs; the success of each project depends on the social, economic, political and cultural context of the community where the project is to be implemented [30]. Careful assessment of the local context, including the appropriateness of different renewable energy sources, is thus necessary.

\subsection{Grid vs. off-grid solutions}

Which technology is appropriate depends, among other things, also on the location of a specific projects. In particular, remote rural areas, as on outer islands, have very different preconditions than urban centres on the main island(s). For the former, standalone off-grid solutions are needed, while grid solutions tend to be available for the latter.

In the OECD CRS, most projects lacked information about whether they focused on grid or off-grid solutions, or both (see Fig. 5). Of the 328 renewable energy project entries, only 109 project entries, representing 47 percent of commitments, contained information

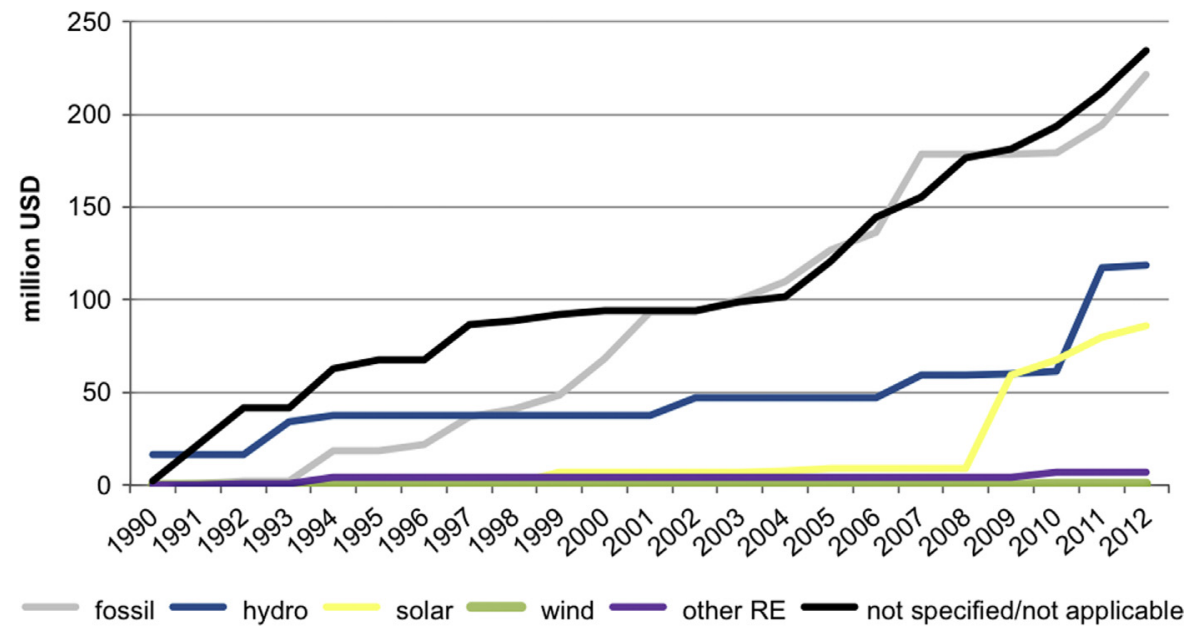

Fig. 4. Aid for renewable energy to the Pacific island countries, by energy source. Source: Based on oECD CRS Dataset.

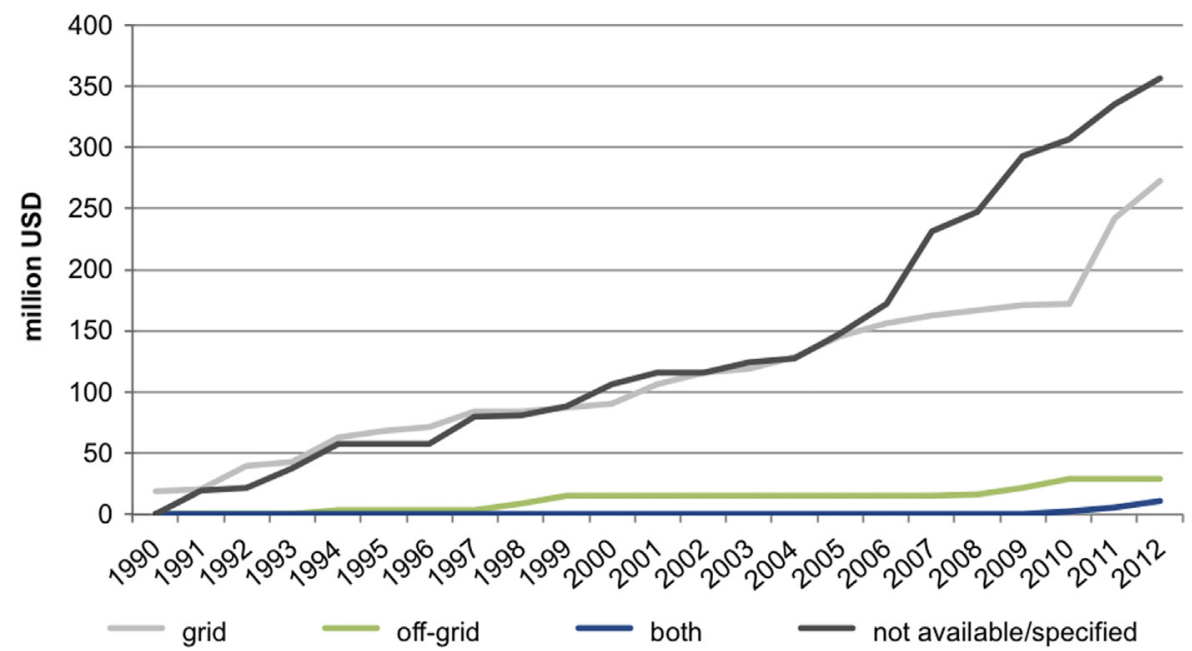

Fig. 5. Aid for renewable energy to the Pacific island countries, by grid/off-grid focus. Source: Based on OECD CRS Dataset. 
on grid vs. off-grid approaches. 273 million USD were committed to grid-solutions, while 29 million uSD were spent on off-grid solutions; projects worth 11 million usD targeted both grid and off-grid solutions. Spending on off-grid solutions increased in 2008, in line with increased spending on solar power - many of the solar home systems focus on remote rural areas, as described earlier.

Grid-based electricity is often more popular with households, since the grid provides more reliable electricity, compared to a diesel generator that runs only a few hours per day - or not at all, as when awaiting repair or fuel $[4,9,23]$. Extension of the grid also provides more economic benefits, as well as cheaper electricity compared to off-grid solutions [31]. However, grids are mostly available only on the main island(s), and thus privilege urban populations, who already tend to be better off economically than rural populations in remote islands - where a large part of the Pacific population lives. Grid extension programmes therefore reach households with higher incomes, while off-grid electrification targets households with lower incomes [4, p. 732].

Since demand for energy is comparatively low in remote rural areas, PICs are likely to focus attention on urban areas to meet their ambitious renewable energy goals - areas where inhabitants already have access to (conventional) electricity [4]. Of course, given the high levels of urbanisation in many PICS, the focus on urban areas is justified to some extent, but should not come at the expense of rural electrification programmes. Access to electricity enhances welfare, by for instance facilitating economic activities or enabling storage of medical or food items, and so policy makers should give priority to electrification [4,31]. Additionally, high transportation costs make renewable energy solutions particularly interesting and economically beneficial in remote outer islands and rural areas, e.g. [7].

\subsection{Project components}

In those remote outer islands and rural areas, capacity-building is of great importance, much more so than in urban, gridconnected areas. Capacity-building is part of 'software': social and institutional aspects [30], knowledge as well as managerial and operational skills [32]. The opposite is 'hardware': equipment and infrastructure.

Scholars highlight the importance of the former for the long-term success of renewable energy projects, yet, donors often privilege hardware and neglect software, e.g. $[8,4,24,23]$. Fig. 6 shows the amount of aid going into different project components: equipment and distribution; technical assistance; energy efficiency; capacity- building; policy-making; and other components, such as auditing. Many projects have several components, including for instance equipment as well as training or capacity-building, so Fig. 6 may include the same project in several categories.

Overall, donors spent most aid on equipment, including repair and power distribution infrastructure, with 284 million USD in commitments. Many (recent) projects also have a capacitybuilding and policy-making component to them (85 and 70 million USD, respectively); to a lesser extent, projects focus on energy efficiency (41 million USD) or technical assistance, including consulting and research (51 million USD). Rarely, projects have some other focus, such as auditing or emergency relief ( 1 million USD).

How has this distribution across project components changed over time? Throughout the 1990s, projects focused equally on equipment and distribution and technical assistance. Since about 2001, technical assistance has remained relatively stable, while equipment and distribution has received significant amounts of funding. More recently, projects focused more and more on software, including policy-making - not least to help with devising the ambitious renewable energy goals and policies mentioned earlier, energy efficiency, and capacity-building.

The higher level of funding toward equipment certainly also reflects the higher capital requirements of, for instance, building a dam for a hydropower plant, compared to a training programme or workshop. Nonetheless, more funding needs to be dedicated to training and capacity-building, as donors seem to recognise more and more, especially for rural electrification. Studies again and again cite lack of capacity as the prime reason for the slow progress toward renewable energy, e.g. [16,17,12,33]. Capacity is needed not only at the policy-making level for energy planning and management; capacity is also, and importantly, needed at the local level, especially in rural areas - to operate and maintain equipment. Yet, many projects do not adequately train local people in system operation and management $[8,4,23]$. One study cites a European Union funded solar lighting project where 98 percent of the budget was for project 'hardware', and only 2 percent for project 'software' - a typical budget structure [24]. As one author from the region deplores, 'there has been a tendency to treat renewable technologies as equipment to be sold, leaving users without follow-up support' [8, p. 307].

Yet, this follow-up support, that is, human resources and institutional development are the most important success factors and should receive much more attention, see also e.g. [4,24,23]. Even where donor-funded projects do provide training, such training does not necessarily secure operations and maintenance.

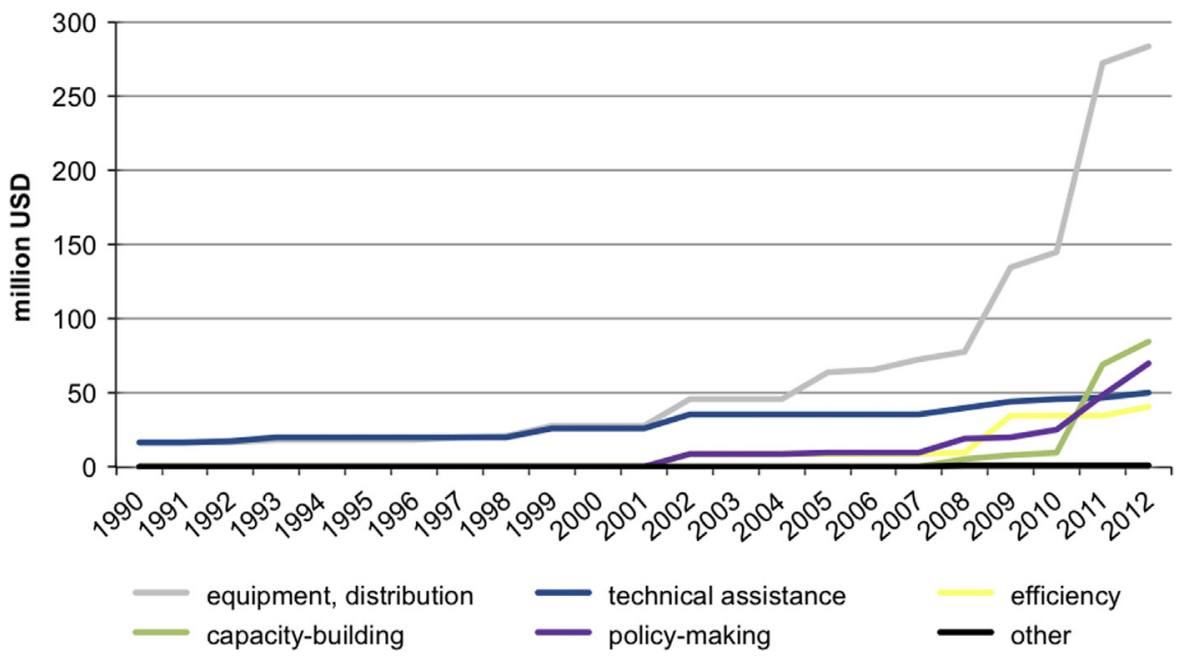

Fig. 6. Aid for renewable energy to the Pacific island countries, by project component. Source: Based on OECD CRS Dataset. 
Often, newly trained village technicians leave their communities: with their new skills, they are now in a better position to find employment in urban areas $[30,24]$. Similarly, users are reluctant to pay for maintenance and repair, and fail to set aside appropriate funds in advance [4,25]. Accordingly, just as with diesel generators, renewable energy systems often fall into disuse when repair is needed, but no technician and/or no spare parts are available, a problem for remote rural communities in particular [23]. As Fig. 6 indicates, donors seem to recognise the challenge and put more emphasis on 'software', that is, capacity-building and training.

\section{Conclusion}

PICS are in an advantageous position to transition toward renewable energy: they have ample renewable energy sources and important economic and environmental reasons to use these. PICS also have the political will to realise this transition, as their ambitious national goals and regional visions show.

For the PICs to reach these goals, however, they depend on donor funding, which has been growing, especially for renewable energy. This paper has taken a closer look at this energy-related aid from 1990 through 2012. Using data from the OECD, it examined in particular its development in three areas: Which energy technology aid supported, whether it targeted grid or off-grid solutions, and to what extent it supported 'hardware' or 'software'.

Although donors continue to provide significant funding for fossil fuel, their emphasis has shifted towards renewable energy over the recent years. Here, most aid supported hydro, and more recently, solar power. A lot of aid went into grid solutions, though again, we can see a recent focus on off-grid projects, with rural electrification projects often using stand-alone solar home systems. Finally, donors invested heavily in 'hardware', that is, equipment, infrastructure and distribution. Again, however, donors have started to invest more in 'software', in capacity-building programmes and training, or policy-making.

Admittedly, the analysis here may underestimate spending on renewable energy, on off-grid solutions or capacity-building, since many project entries in the OECD creditor reporting system lack informative project titles or descriptions, and are hence not represented adequately in the dataset. Nonetheless, the analysis offers some insights in how energy-related aid to the Pacific has been spent, and provides evidence for a shift in donor thinking toward renewable energy, including in remote rural areas and including capacity-building. While much remains to be done, this leaves us with hope for a successful transition to clean and secure energy in the Pacific. Small island states, in the Pacific and elsewhere, are well positioned to serve as examples and role models on renewable energy for other countries, developing and developed, islands and non-islands.

\section{Acknowledgements}

I would like to acknowledge funding from the Gothenburg Centre for Globalisation and Development that made this research possible.

\section{Appendix. Description of the dataset}

The OECD'S Creditor Reporting System provides detailed information on individual aid activities, including recipients, sectors and project descriptions. I obtained the complete files on individual aid activities from 1990 to 2012 from the OECD.Stat website, ${ }^{3}$ and extracted all aid activities with a Pacific island country or Oceania as a region as recipient. I then identified all energy-related aid activities. Here, I included all project entries with the sector name 'Energy', as well as project entries where the project title and/or the short or long project descriptions contained any of the following key words: energy, power, fuel, petroleum, oil, gas, solar, hydro, wind, biomass, grid. This yielded a dataset with a total of 699 project entries - although this does not correspond to 699 different projects, as some projects may be associated with several project entries, for example when several donors contribute to a project. I only collapsed projects with more than one project entry if a project had a project entry in the year in which the donor committed funding as well as in the year in which the donor disbursed that funding.

In a second step, I used the project titles, short and long project descriptions and purpose names to code for a project entry's energy technology, project components and focus on the grid or off-grid. Under project components, I categorised project entries according to whether funding was available for equipment (including repair and power transmission), energy efficiency, capacity-building and training, policy-making (including planning), research, consulting and technical assistance, or other components like for instance auditing or emergency relief. Unfortunately, for a number of project entries, not enough information was available to identify the technology, project components and/or grid/off-grid focus.

To give an example of the coding: For a 2011 United Nations Development Programme project in Tuvalu, 'Tuvalu Sustainable Energy Inte', included the following project description: 'The objective of the project is to raise public awareness on energy conservation and energy efficiency in Tuvalu, develop capacity of technicians to maintain solar-diesel hybrid systems and the solar PV stand-along home systems in outer islands. The capacity development of technicians component would provide additional resources to the proposed Italian funded renewable energy project "Tuvalu Photovoltaic Electricity Network Integration (TPVENI)" and would nationally executed through Cost-Sharing Agreement. It is also foreseen that the project would mobilize resources from the Government of India, as agreed at the 2006 post-Forum dialogue and nationally executed through Cost-Sharing Agreement.' I categorised this project as a renewable energy project using solar energy, with energy efficiency and capacity-building/training as project components, and a focus on off-grid solutions.

To ensure coding reliability, a second coder independently coded a subset of the dataset of 34 randomly selected project entries, corresponding to five percent of the complete dataset. The intercoder reliability for this subset of the database was 82 percent.

\section{References}

[1] Roper T. Small island states-setting an example on green energy use. Rev Eur Commun Int Environ Law 2005;2:108-16.

[2] Weir T, Orcherton D. Climate change issues on the Pacific islands: an overview. In: Filho WL, Mannke F, Mohee R, Schulte V, Surroop D, editors. Climate-smart technologies. Berlin, Heidelberg: Springer-Verlag; 2013. p. 51-64 (Chapter 4).

[3] Mofor L, Isaka M, Wade H, Soakai A., Pacific Lighthouses: renewable energy roadmapping for islands., Technical report, International Renewable Energy Agency, Abu Dhabi; 2013.

[4] Dornan M. Access to electricity in small island developing states of the Pacific: issues and challenges. Renew Sustain Energy Rev 2014;31:726-35.

[5] Briguglio L. Small island developing states and their economic vulnerabilities. World Dev 1995;23(9):1615-32.

\footnotetext{
${ }^{3}$ See http://stats.oecd.org.
} 
[6] Singh A, Fifita S, Mario R, Bijay P, Singh A. Sustainable energy development in the Pacific: the evolution of energy frameworks and national policies. In: Filho WL, Mannke F, Mohee R, Schulte V, Surroop D, editors. Climate-Smart technologies integrating renewable energy and energy efficiency in mitigation and adaptation responses. Heidelberg: Springer; 2013. p. 129-40 [Chapter 10].

[7] Woodruff A. An economic assessment of renewable energy options for rural electrification in Pacific island countries, Technical report, Pacific Islands Applied Geoscience Commission (SOPAC), Suva; 2007.

[8] Jafar M. Renewable energy in the south Pacific-options and constraints. Renew Energy 2000;19:305-9.

[9] Woodruff A. Are renewable energy technologies a cost-effective option for promoting rural electrification in Pacific island countries? Paper prepared for the 24th Science, Technology and Resources Network (STAR) Conference, Nuku'alofa, Tonga, November 2007; 2007.

[10] Weisser D. Power sector reform in small island developing states: what role for renewable energy technologies?. Renew Sustain Energy Rev 2004:8:101-27.

[11] IRENA. Policy challenges for renewable energy deployment in Pacific island countries and territories, IRENA Policy Brief, International Renewable Energy Agency, Abu Dhabi; 2012.

[12] Singh A. Renewable energy in the Pacific Island countries: resources, policies and issues. Manag Environ Qua Int J 2012;23(3):254-63.

[13] CROP (Committee of Regional Organizations of the Pacific). Pacific islands energy policy and plan, Pacific Regional Energy Meeting convened in the Cook Islands, 15-19 July 2002. Available online at 〈http://www.forumsec.org/ resources/uploads/attachments/documents/Pacific $\rangle$.

[14] SPC. Towards an energy secure Pacific: a framework for action on energy security in the Pacific, Secretariat of the Pacific Community, Nouméa, New Caledonia; 2011.

[15] United Nations. Sustainable energy for all; 2013. 〈http://www.se4all.org/〉.

[16] Niles K. Energy aid in Caribbean and Pacific small island developing states (SIDS) (Ph.D. thesis). University of Otago, Dunedin, New Zealand; 2012.

[17] Niles K, Lloyd B. Small island developing states (sIDS) \& energy aid: impacts on the energy sector in the Caribbean and Pacific. Energy Sustain Dev 2013;17:521-30.

[18] Yu X, Taplin R, A Survey: International aid for renewable energy in the Pacific islands since the 1970s, Energy Policy 255 (1997) 501-516.

[19] Organisation for Economic Co-operation and Development, Information note on the DAC Deflators; 2015 Available online at 〈http://www.oecd.org/dac/ stats/informationnoteonthedacdeflators.htm>.

[20] Mitra I. A renewable island life: electricity from renewables on small islands, reFOCUS Available from 〈http://www.re-focus.net〉.

[21] Mala K, Schläpfer A, Pryor T. Solar photovoltaic (PV) on Atolls: sustainable development of rural and remote communities in Kiribati. Renew Sustain Energy Rev 2008;12:1345-63.

[22] Weisser D. On the economics of electricity consumption in small island developing states: a role for renewable energy technologies?. Energy Policy 2004:127-40.

[23] Weir T, Prasad S. Adoption of climate-smart technologies: the case of rural solar electricity in the Pacific islands. In: Filho WL, Mannke F, Mohee R, Schulte V, Surroop D, editors. Climate-Smart technologies integrating renewable energy and energy efficiency in mitigation and adaptation responses. Heidelberg: Springer; 2013. p. 379-92 [Chapter 28].

[24] H. Outhred, S. Healy, M. Retnanestri, T. Tukunga, Experience with off-grid photovoltaic systems in Tonga and Indonesia, 14th International photovoltaic science and engineering conference, Bangkok, 2004, 26-30 January 2004.

[25] Mala K, Schläpfer A, Pryor T. Better or worse? the role of solar photovoltaic (pv) systems in sustainable development: case studies of remote atoll communities in Kiribati Renew Energy 2009;34(2):358-61.

[26] Yin MTP, Jayasuriya J, Fransson T, Dinesh S, Romeela M. Assessment of the most sustainable renewable energy configuration in Mauritius and Rodriques. In: Filho WL, Mannke F, Mohee R, Schulte V, Surroop D, editors. Climate-Smart technologies integrating renewable energy and energy efficiency in mitigation and adaptation responses. Heidelberg: Springer; 2013. p. 365-75 Ch. 27.

[27] Praene JP, David M, Sinama F, Morau D, Marc O. Renewable energy: progressing towards a net zero energy island, the case of reunion island. Renew Sustain Energy Rev 2012;16:426-42.

[28] Dornan M, Jotzo F. Renewable technologies and risk mitigation in small island developing states: Fiji's electricity sector. Renew Sustain Energy Rev 2015;48:35-48.

[29] Prasad S, Kumar A, Raturi A. Optimization of a stand-alone renewable energy system for a small load requirement. In: Filho WL, Mannke F, Mohee R, Schulte V, Surroop D, editors. Climate-Smart technologies integrating renewable energy and energy efficiency in mitigation and adaptation responses. Heidelberg: Springer; 2013. p. 615-28 Ch. 46.

[30] Dornan M. Solar-based rural electrification policy design: the renewable energy service company (resco) model in Fiji. Renew Energy 2011;36:797-803.

[31] World Bank, The welfare impact of rural electrification: a reassessment of the costs and benefits: an IEG impact evaluation, Technical report, Independent Evaluation Group, Washington, D.C.; 2008

[32] van Alphena K, Hekkert MP, van Sark WG. Renewable energy technologies in the Maldives-realizing the potential. Renew Sustain Energy Rev 2008; $12: 162-80$

[33] GEF, Pacific Islands Greenhouse Gas Abatement through Renewable Energy Project (PIGGAREP) Project Brief, United Nations Development Programme Global Environment Facility. Available online at. 〈http://www.thegef.org/gef/ project_detail?projID $=2699$.

[34] IRENA. Renewable Energy Country Profiles, Special edition on the occasion of the renewables and islands global summit 6-7 September 2012, International Renewable Energy Agency, Abu Dhabi; 2012.

[35] World Bank. World Development Indicators; 2014. Available online at 〈http:// databank.worldbank.org/Data/Home.aspx>.

[36] CIA (Central Intelligence Agency). The World Factbook; 2013. Available online at 〈http://www.cia.gov/library/publications/the-world-factbook/geos/ne.html〉.

[37] Legros G, Havet I, Bruce N, Bonjour S. The energy access situation in developing countries: a review focusing on the least developed countries and SubSaharan Africa, United Nations Development Programme; November 2009.

[38] SPC. Country Energy Security Indicator Profiles 2009, Secretariat of the Pacific Community; 2012. Available online at. 〈http://www.spc.int/edd/section-01/ energy-overview $\rangle$. 